\title{
ACTUARIAL VALUATION OF PENSION SCHEMES: AN IRISH PERSPECTIVE
}

\author{
Bridget McNally and Thomas O'Connor \\ Department of Economics, Finance and Accounting, \\ National University of Ireland Maynooth
}

\begin{abstract}
$\mathrm{T}$

The liabilities of a pension plan are monetary amounts to be paid at various times in the future. The current legal and regulatory framework for Irish occupational pension schemes can result in three different valuations for a scheme at any particular point in time. Using valuation models, this paper considers whether across the three different valuation bases there is consistency in the sensitivity of the reported results to changes in the key actuarial assumptions and what are the most sensitive assumptions under each calculation basis. It questions whether this current valuation framework creates potential hazards for scheme trustees who are charged with governance of the scheme and are ultimately responsible for the key decision-making processes within the scheme.
\end{abstract}

\section{INTRODUCTION}

The pensions system in Ireland (in common with many other countries) has two main elements, a state-run social welfare system and a system of private, voluntary, supplementary pensions provided through a variety of arrangements and regulated by the state. A sizeable proportion of voluntary pension arrangements take the form of occupational pension schemes, that is, privately managed pension schemes offered by employers to some or all employees as part of an overall remuneration package. These schemes are funded by contributions by the employer and also in many cases the employees, the objective being that the contributions together with the return from the investment of the contributions will provide a targeted level of replacement income on retirement to complement the employee's social security pension. 
For employees, the vast majority of voluntary pension arrangements are either defined benefit (DB) or defined contribution (DC) schemes. A DB scheme is one where the pension on retirement is fixed in advance, usually as a proportion of the member's salary in their last year of service or based on an average of their annual earnings over a number of years. The level of contribution by the employer/ employee is set at a level which is actuarially calculated to produce the targeted pension on retirement. In the event of a shortfall, the employer commits to making up the deficit so that the promised level of pension is met. The risk for the employee in a DB scheme is that the employer is financially unable or unwilling to honour this guarantee. A DC scheme defines the contribution to be made by the employer and the employee rather than the benefit promised on retirement. DC schemes do not have an employer guarantee (all investment risk is borne by the employee). In the absence of this guarantee, pension payments are a function of the employee's 'accumulated pension fund' on his/her retirement date.

The principal objective of any pension arrangement is that it meets its targeted pension liabilities as they fall due. At any particular point in the life of a pension scheme, its ability to meet its targeted pension liabilities can (and is required by regulation to) be assessed, although this can only be a best estimate given that the future is always uncertain. A valuation exercise for a DB scheme requires assessment of both the scheme's assets and its liabilities. While there may be some subjectivity in the valuation of certain types of assets (where for example there is no ready market (more prevalent during recessionary times) or where it is considered appropriate to use a smoothed value), the main area of estimation arises in relation to the valuation of liabilities. This is further complicated in the Irish context by the fact that the basis of valuation is different, depending on whether the valuation is for the regulator, the scheme trustees or the sponsoring company's shareholders. The issue is complicated further still, at least for stakeholders, by the fact that disclosures as to the sensitivity of a valuation result to key valuation assumptions are minimal or, in some instances, non-existent (see O'Brien, Woods and Billings (2010) for example in the case of International Accounting Standard No. 19 (IAS 19) disclosures by relevant FTSE 100 companies).

These issues are important because the flexibility in assumption setting and the lack of standardised sensitivity analysis disclosures in annual reports create potential hazards for scheme trustees who are charged with governance of the scheme and are ultimately responsible for the key decision-making processes within the scheme. Most Irish pension schemes are legally structured as trusts ${ }^{1}$ and the board of trustees of the scheme has ultimate responsibility for the management of the pension scheme's affairs. ${ }^{2}$ While trustees may take advice from appropriate experts, case law ${ }^{3}$ has held that " It is for advisors to advise and for trustees to decide"' (Scott $v$ National Trust for Places of Historic Interest or Natural Beauty (1998), quoted in Delaney, 2007, p. 458). Consequently, the existence of three valuation frameworks, flexibility in assumption setting, inconsistency in importance of actuarial assumptions across the three frameworks and non-standardised sensitivity disclosures potentially provide a challenge for trustees in fulfilling their trustee duties, notwithstanding the availability of expert advice from third parties. A new era for scheme trustees has arrived where trustees are required to oversee in some cases 
pension scheme closure and in others considerable pension scheme restructuring, such as changes in pension entitlements and increased contributions. The current recession is the first time for many schemes to encounter deficits which threaten the viability of many schemes, with consequent implications for the role and liability of trustees. It follows that when pension schemes fail to deliver on pension promises, scheme trustees are accountable to scheme members for their actions. Trustees could have a case to answer if they are found to have presided over periods where actuarial assumptions adapted were ultimately found to be less than realistic.

With this in mind, the principal objective of this paper is to consider, in the context of DB pension schemes, whether the existing valuation framework in Ireland - which requires a different calculation basis depending on whether the valuation is for the regulator, the scheme members or the sponsoring company's shareholders - incorporates a level of flexibility, complexity and disjointedness which poses challenges for trustees charged with governance of pension schemes. Second, the paper considers whether across the three different valuation bases there is consistency in the sensitivity of the reported results to changes in the key actuarial assumptions and what the most sensitive assumptions under each calculation basis are. ${ }^{4}$ While it is well established in the international literature that changes in key assumptions can and do have a significant impact on valuation results (see Lane Clarke \& Peacock, 2008 for example), work in this area in the Irish context and the implications of such flexibility for scheme governance is minimal. ${ }^{5}$ Finally, the paper considers the consequent practical issues for trustees charged with the governance of pension schemes.

The paper proceeds as follows. In the next section, we describe the three valuation models which form the framework for the valuation of pension scheme liabilities in Ireland. The third section describes our methodology and approach. The following three sections discuss our principal findings and the practical implications. The final section concludes.

\section{WHY ARE ACTUARIAL LIABILITIES CALCULATED?}

The valuation of a DB pension scheme's assets and liabilities is required in at least three different circumstances. It may be required for the purposes of determining whether the fund satisfies the minimum funding standard valuation set down by the regulatory authority. The fund trustees may also require a valuation for the purposes of their annual trust report to the members of the pension scheme, and to review contribution rates. Finally, in the case of a DB scheme, a valuation may be required for the purposes of the financial statements of the sponsoring company, to recognise the 'fair value' of the surplus or deficit in the pension scheme.

What is interesting is that there is no specific requirement for consistency in the valuation assumptions used in each of the three valuation processes. At any given valuation date therefore, a DB scheme may have three different valuation results, required for three different purposes, each of which would be regarded as fully acceptable for its specific purpose and to its specific target audience. Indeed, as can 
be seen in subsequent paragraphs, the prescribed guidelines to be followed in each of the three valuation processes in themselves necessitate differing assumptions and calculation bases and different emphases in the produced results.

Existing literature recognises that there can be considerable discretion in the choice of assumptions used to estimate pension liabilities. This is reflected in a debate within the actuarial profession on alternative valuation approaches to pension scheme assets and liabilities. MacDonald (1993), in his discussion of the actuarial valuation exercise for the purposes of determining the solvency or otherwise of a life insurance business, recognises that a valuation basis is an extremely simple model of the future, usually modelling interest and inflation as constants, but that actual experience is unlikely to resemble the model used, either quantitatively or qualitatively. Pemberton (1998) argues that the traditional actuarial discounted cash flow approach to valuing pension fund assets and liabilities, which is largely based on discounted cash flows, can differ significantly to the value of pension fund assets using current market prices. He also, however, questions the pricing approach which uses current market prices on the basis that this approach has serious limitations in both a theoretical and practical sense. Connell (2007) refers to the plethora of assumptions which must be examined in assessing different proposals/ models for future pension provision. Attain Consulting (2009), in a study of the valuation of scheme surpluses/deficits for financial reporting purposes, considers the impact of the discount rate (which is based on long-term corporate bond rates) used in the actuarial valuation calculation of the deficits of pension schemes of companies quoted on the Irish Stock Exchange. The author argues that the deficits on such schemes estimated at the time of the report to be $€ 3.5$ billion or between 12 per cent and 14 per cent of the market capitalisation of the sponsoring companies, and would have represented 40 per cent of the market value of the companies if bond yields had not risen in 2008.

For the remainder of this paper we will refer to the alternate valuations required for the purposes of the regulator, the trustees and sponsoring company's financial statements as the minimum funding standard (MFS), trustee and IAS 19 valuations respectively. In what follows, we briefly describe the most salient features of each in turn.

\section{The MFS Valuation}

The objective of the MFS valuation is effectively to establish whether the scheme is holding sufficient assets to meet the benefits which have already accrued to members at the date of the valuation, i.e. if the scheme were to be wound up on the valuation date. Irish pension schemes are regulated by the Pensions Board, a statutory body set up by the Irish government under the Pensions Act 1990. The MFS was introduced by the Pensions Board in 1991 (it was provided for in section 44 of the Pensions Act 1990) in order to set out the minimum assets that a DB scheme must hold and what steps must be taken if the assets of the scheme fall below this minimum. The funding standard is satisfied if, broadly, in the actuary's opinion, the scheme's assets on the date of the valuation are more than the sum of: (1) the transfer values at that date (see below) to which the members would be entitled, and (2) the estimated expenses of winding up the scheme. 
All pension schemes are required to register with the Pensions Board and, subject to some exceptions, ${ }^{6}$ all DB schemes must submit an Actuarial Funding Certificate (AFC) to the Board every three years. This certificate states whether, in the actuary's opinion, the resources of the scheme would/would not be sufficient, if the scheme were wound up, to provide for the liabilities of the scheme under the Pensions Act, and the estimated expenses of administering the winding up of the scheme, i.e. whether the scheme satisfies the funding standard of the Act.

If an AFC indicates that, in the actuary's opinion, the scheme does not satisfy the funding standard, the scheme trustees must submit a funding proposal with the AFC to the Pensions Board. The funding proposal must set out the contribution plan to be undertaken which the scheme actuary can certify as being sufficient to allow the scheme satisfy the funding standard within the period of the proposal. The period of the proposal was restricted to three years up until 2003 but since 2003, given the growing number of DB schemes in deficit, the Pensions Board has allowed in certain circumstances a longer period of exemption.

The guidelines to be followed by a scheme actuary in valuing the assets and liabilities of a pension scheme for the purposes of determining whether it complies with the funding standard are included in Actuarial Statements of Practice (ASP PEN 3 and ASP PEN 2), issued by the Society of Actuaries in Ireland (2012 and 2013) and periodically updated. ${ }^{7}$ The legal basis for the guidelines is section 42(4) of the Pensions Act 1990, which refers to 'applicable professional guidance issued by the Society of Actuaries in Ireland'.

For the purposes of the funding standard, assets must be valued at their realisable value at the effective date with allowance being made for the expenses of sale where appropriate. Liabilities can broadly be split between pensions currently payable to pensioners and deferred pension entitlements (for all active members, i.e. employees and former employees who have not yet reached retirement age and have future pension entitlements from the scheme). The cost of pensions in payment can be determined by reference to the cost of an equivalent annuity or annuities. The value of deferred pension entitlements is taken as the individual transfer values to which each member would be entitled if he/she had transferred out of the scheme at that date. The transfer is calculated by projecting the benefit payments to which the members will be entitled based on their employment to date, including an appropriate margin for mortality improvement and assuming a prescribed investment return rate as a discount factor, calculating the size of the fund required in today's terms to meet the projected benefit payments. The prescribed investment return is calculated assuming investment in equities (assumed to generate a return in excess of the fixed interest rate, i.e. an equity premium or a return over and above the fixed interest rate to compensate for the fact that equities are a riskier investment) until ten years before normal retirement age and thereafter a mix of equity and fixed interest investments with the proportion of fixed interest investments gradually increasing to 100 per cent by normal retirement age.

The Society of Actuaries in Ireland (2008) recommends that to improve benefit security the minimum funding legislation be strengthened by requiring that liabilities be valued on an 'economic basis' (present value of the benefit promise based on prevailing yields on government fixed-interest stock of a suitable term and realistic 
estimates of mortality, including allowance for future mortality improvements). This significantly higher figure would be divided into a minimum funding level with a requirement to repair under-funding below this level over a nine- to twelvemonth period and a higher 'target funding level' (Society of Actuaries in Ireland, 2008 , p. 4.5) with scope to address under-funding below this level over a longer (fifteen-year) period. Provisions were introduced (Social Welfare and Pensions Act 2012) strengthening the funding standard by requiring the preparation of a Funding Reserve Certificate, which effectively states whether the scheme could meet its liabilities if interest rates were to fall by 0.5 per cent (or such other rate as the Minister for Social Protection may direct). With effect from January 2016, DB schemes will be required to hold a risk reserve as a protection against such investment return volatility.

\section{The Trustee Valuation}

Section 56 of the Pensions Act 1990 (supplemented by S.I. No. 301 of 2006) requires the trustees of a DB pension scheme to have audited financial statements produced annually for the scheme and to have the assets and liabilities of the scheme valued by the actuary of the scheme at such times as may be prescribed. When the legislation was first introduced, the requirement was for a valuation every three or three and a half years, depending on the nature of the scheme and when it was established. With effect from 23 September 2005, the period between valuations became three years for all schemes. The main purpose of this valuation is to assess an appropriate funding/contribution rate from the employer/employees for the scheme.

Actuarial Standard of Practice PEN 1 (ASP PEN 1) Funding Defined Benefits Actuarial Reports (Society of Actuaries in Ireland, 2010) ${ }^{8}$ sets out the blueprint for actuaries carrying out a valuation for the purposes of section 56 of the Pensions Act 1990. A valuation report issued in accordance with ASP PEN 1 must state the value of the schemes' assets (at market value), and a statement of the benefits payable under the scheme. This will include the value of accrued liabilities (in respect of past service) and liabilities in respect of future service. It should also state the funding level on which the valuation is based and recommend the level of contribution required, consistent with the funding objectives of the scheme until the next actuarial valuation. The level at which the employer and/or the employees must contribute to the scheme in order to meet their commitments under the scheme, i.e. the funding level, will be based on a wide variety of assumptions. These include projected rates of return on contributions invested, numbers and ages of members entering and leaving the scheme, mortality rates of members, early retirement rates and salaries of members on retirement. These assumptions can be estimated based on previous experience (for example, mortality rates) and expectations for the future (for example, future returns). ASP PEN 1 states that it is not intended to restrict the actuary's freedom of judgement in choosing the method of valuation and the underlying assumptions employed in deriving the level of contribution required but it is intended to ensure that the methods and assumptions used are properly explained, the sensitivity of the results to the assumptions chosen are set out and that variations between the assumptions chosen and actual experience are analysed in the report. The report must contain a summary of the demographic 
and economic assumptions made explicitly and implicitly in valuing the liabilities, target benefits and scheme assets.

The level of subjectivity in a trustee valuation is far greater than in an MFS valuation given that the former valuation will encompass assumptions on future outcomes in a number of key areas. With effect from 2011, the law requires that the trustees' annual report to scheme members must also include a copy of the latest Actuarial Funding Certificate together with an up-to-date actuarial statement of the schemes' funding position at the last date of the period to which the annual report relates. A trustee annual report may therefore incorporate references to two different valuation processes. The challenge currently for trustees is to understand and reconcile these different valuation processes. Notwithstanding the existence of investment advisers to the scheme, trustees could find themselves exposed to a legal challenge for non-performance of duties if they are not informed sufficiently as to the robustness of the valuation results and try to abdicate their responsibilities in this regard in favour of the actuary.

\section{The IAS 19 Valuation}

Accounting for DB plans in the financial statements of the sponsoring company is a complex matter. The complexity arises because the employer must, in each accounting period, recognise as an expense in its income statement/profit and loss account the cost to the employer of the retirement benefits that will eventually be paid to employees as a result of the services that they have provided during the period. Because these benefits may be payable in many years' time and their cost will depend on a number of factors that are difficult to determine in advance (mortality, return on investments, etc.), the calculation of the expense which should be recognised in an accounting period is not straightforward. As the sponsoring company potentially carries the risk of any shortfall arising on a DB scheme (i.e. if amounts contributed by both the employer and the employee, together with the net investment return on such contributions are insufficient to pay the scheme pensions and benefits as they fall due), such a shortfall, if it were to exist, could constitute a medium- to long-term liability of the sponsoring company, over and above its annual funding commitment, and needs to be recognised as such in the sponsoring company's financial statements. The converse also applies in that any excess of assets in the pension scheme (i.e. surplus) which could reduce the sponsoring company's payments or commitments in the future could also be required to be recognised as an asset in its financial statements.

The International Accounting Standard No. 19 (IAS 19) (International Accounting Standards Board, 2008) provides the internationally recognised guidance on accounting for and disclosure in financial statements of DB pension benefits and obligations. The first stated objective of IAS 19 is to ensure that an employer's balance sheet reflects a net pension liability/asset in respect of employee benefits to be paid in the future. This is known as the 'balance sheet' approach. The second stated objective of IAS 19 is to ensure that the employer's income statement recognises an expense when the employer consumes an economic benefit arising from the services provided by the employee in exchange for employee benefits. 
Accounting for DB plans is complex because actuarial assumptions and valuation methods are required to measure the balance sheet obligation/asset and the income statement expense. The plan liabilities (the DB obligation) and the plan assets are measured at each balance sheet date. The plan assets are measured at fair value (not necessarily the same as either net realisable value or market value). The DB obligation is measured on an actuarial basis and discounted to present value. This requires assumptions on mortality, both during and after employment; rates of employee turnover, disability and early retirement; the proportion of plan members with dependants who will be eligible for benefits; and claim rates under medical plans. The liability must then be discounted back to the current valuation date using the yield on high quality corporate bonds (AA).

Lane Clarke \& Peacock Ireland (2009) noted from the IAS 19 valuations of 29 Irish schemes reviewed that widely varying assumptions were used in key areas across the schemes. Life expectancy assumptions adapted by the schemes surveyed ranged from 83.5 years to 87.1 years for a male and 86 years to over 90 years for a female. Discount rate assumptions (based on 'high quality' corporate bond rates) ranged from under 5.6 per cent to 6.5 per cent; inflation assumptions ranged from 1.75 per cent to 2.5 per cent; and expected return on equities ranged from 7 per cent to 9 per cent.

Table 1 summarises the principal characteristics of the MFS, trustee and IAS 19 valuation models.

TABLE I: COMPARISON OF THE THREE VALUATION APPROACHES TO MEASURING PENSION FUND PERFORMANCE

This table summarises how pension scheme assets and liabilities are to be valued for regulatory purposes (MFS), for trustee reporting purposes and for inclusion in the financial statements of sponsoring companies (IAS 19).

\begin{tabular}{|c|c|c|c|}
\hline & \multicolumn{3}{|c|}{ Valuation Approach } \\
\hline & $\begin{array}{c}\text { Minimum Funding } \\
\text { Standard (ASP PEN 3) }\end{array}$ & $\begin{array}{c}\text { Trustees Ongoing } \\
\text { Valuation (ASP PEN I) }\end{array}$ & $\begin{array}{c}\text { Accounting Approach } \\
\text { (IAS I9) }\end{array}$ \\
\hline Valuation of Assets & Realisable value & Market value & Fair value \\
\hline $\begin{array}{l}\text { Valuation of } \\
\text { Liabilities }\end{array}$ & $\begin{array}{l}\text { Annuity cost of pensions } \\
\text { in payment plus transfer } \\
\text { values of deferred } \\
\text { pensions }\end{array}$ & $\begin{array}{l}\text { Final estimated liability } \\
\text { discounted back to } \\
\text { valuation date and } \\
\text { apportioned between } \\
\text { past and future service }\end{array}$ & $\begin{array}{l}\text { Final estimated liability, } \\
\text { based on service to } \\
\text { date, discounted back to } \\
\text { balance sheet date }\end{array}$ \\
\hline Discount Rate & $\begin{array}{l}\text { Prescribed rate of } \\
\text { investment return pre- } \\
\text { and post-retirement } \\
\text { which assumes an equity } \\
\text { premium in the period } \\
\text { prior to retirement }\end{array}$ & $\begin{array}{l}\text { Assumed expected return } \\
\text { on investments }\end{array}$ & $\begin{array}{l}\text { Yield on high quality } \\
\text { corporate bonds }\end{array}$ \\
\hline
\end{tabular}


TABLE I: (CONTINUED)

\begin{tabular}{|c|c|c|c|}
\hline & \multicolumn{3}{|c|}{ Valuation Approach } \\
\hline & $\begin{array}{c}\text { Minimum Funding } \\
\text { Standard (ASP PEN 3) }\end{array}$ & $\begin{array}{c}\text { Trustees Ongoing } \\
\text { Valuation (ASP PEN I) }\end{array}$ & $\begin{array}{c}\text { Accounting Approach } \\
\text { (IAS I9) }\end{array}$ \\
\hline Mortality & $\begin{array}{l}\text { Based on most recent } \\
\text { mortality tables but with } \\
\text { assumptions on future } \\
\text { trends }\end{array}$ & $\begin{array}{l}\text { Based on most recent } \\
\text { mortality tables but with } \\
\text { assumptions on future } \\
\text { trends }\end{array}$ & $\begin{array}{l}\text { Based on most recent } \\
\text { mortality tables but with } \\
\text { assumptions on future } \\
\text { trends }\end{array}$ \\
\hline Annuity Factor & $\begin{array}{l}\text { Based on mortality } \\
\text { assumptions and the gap } \\
\text { between the expected } \\
\text { rate of pension increase } \\
\text { and the discount rate }\end{array}$ & $\begin{array}{l}\text { Based on mortality } \\
\text { assumptions and the gap } \\
\text { between the expected } \\
\text { rate of pension increase } \\
\text { and the discount rate }\end{array}$ & $\begin{array}{l}\text { Based on mortality } \\
\text { assumptions and the gap } \\
\text { between the expected } \\
\text { rate of pension increase } \\
\text { and the discount rate }\end{array}$ \\
\hline
\end{tabular}

\section{METHODOLOGY AND APPROACH}

We construct three valuation models, one for each valuation basis (MFS, trustee and IAS 19). For comparative purposes we construct a base case of a 40 -year-old female who joined the scheme at age 30 and plans to retire at age 65. We make assumptions on other core variables necessary for the purposes of determining the three alternate valuations for our base scenario (see Table 2 for base case data). The three valuation results are different, in fact very different (see Table 3). For example, the MFS valuation is $€ 50,490$ while the IAS 19 valuation is $€ 125,764$. Yet all three results could be regarded as reasonable and acceptable depending on the target audience and the objective of the valuation. The high level of assumption underlying each calculation is evident.

\section{TABLE 2: BASE CASE}

For comparative purposes, we construct a base case incorporating the key assumptions set our below. The base case data facilitate comparison across the three valuation models and are used to highlight the sensitivity of the valuation models to changes in the key assumptions.

\begin{tabular}{ll}
\hline \multicolumn{1}{c}{ Base Case Characteristic } & \multicolumn{1}{c}{ Value } \\
\hline Employee (Female) - Age & 40 years of age \\
Joined Scheme & 30 years of age \\
Status & Active \\
Retirement Age & 65 years of age \\
Expected Lifetime & 94.5 years of age (based on latest available mortality tables) \\
Current Salary & $€ 45,000$ \\
Expected annual rate of salary increase & $5 \%$ \\
Expected annual rate of pension increase & $2.5 \%$ (assume this is also the rate prescribed by the \\
& Pensions Board for MFS valuation) \\
\hline
\end{tabular}

(Continued) 
TABLE 2: (CONTINUED)

\begin{tabular}{ll}
\hline \multicolumn{1}{c}{ Base Case Characteristic } & \multicolumn{1}{c}{ Value } \\
\hline Expected inflation & $\begin{array}{c}2.5 \% \text { (assume this is also the rate prescribed by the } \\
\text { Pensions Board for MFS valuation) }\end{array}$ \\
$\begin{array}{ll}\text { Discount rate - trustee valuation - based } \\
\text { on estimated investment growth rate }\end{array}$ & $7 \%$ \\
$\begin{array}{l}\text { Discount rate - IAS I valuation - based } \\
\text { on Corporate Bond rate (AA) }\end{array}$ & $5.6 \%$ \\
$\begin{array}{l}\text { Discount rate - MFS valuation - based } \\
\text { on prescribed investment returns for pre- } \\
\text { and post-retirement }\end{array}$ & $7.75 \%$ pre-retirement and $4.5 \%$ post-retirement \\
\hline
\end{tabular}

The paper considers whether across the three different valuation bases, there is consistency in the sensitivity of the reported results to changes in the key actuarial assumptions and if not what are the most sensitive assumptions under each calculation basis. We display the sensitivity of the three approaches to changes in the underlying assumptions by recalculating the base calculations to reflect different ranges of the key inputs, namely the discount rate, salary growth, pension increases, retirement age and mortality, with all other inputs held constant at their base values. We calculate the median $z$-score ${ }^{9}$ of each approach using a wider range of key inputs. The relative sensitivity of each valuation result to changes in constituent assumptions becomes apparent as well as the capacity for significant variation in reported results depending on the 'final mix' of assumptions adopted.

\section{THE SUBJECTIVITY OF THE VALUATION PROCESS}

Under a typical Revenue-approved DB pension scheme, ${ }^{10}$ the annual pension entitlement of a scheme member at normal retirement age is calculated as follows: N/60 * pensionable salary (final salary or an average of a number of years' salary, e.g. last three years), where $N$ is the number of years of pensionable employment completed by the scheme member; this cannot exceed 40 years. The member may opt to take part of his/her pension entitlement as a lump sum on retirement and a correspondingly reduced annual pension thereafter. The calculations are relatively straightforward once the scheme member reaches retirement age. The difficulty arises in estimating accurately what the final pension entitlement (and hence the scheme's liability to each member) will be at any point before the member reaches normal retirement age.

A number of variables used in the calculation require further elaboration:

1. The number of years of pensionable employment equals the number of years the member will be in the scheme if he/she remains working for the scheme employer until normal retirement age. Tax legislation sets the maximum pension entitlement for a tax-approved pension scheme at 1/60 of the final pensionable salary for every year of completed service subject to a maximum of $40 / 60$. 
2. Pensionable salary is expected salary on retirement or some average salary, calculated based on expected annual earnings over a number of years up to the date of retirement. Expected salary at the date of retirement is current salary increased by the estimated annual rate of salary increase for each year remaining up to retirement. Generally the expected salary on retirement is reduced to reflect the fact that the pensioner will be entitled to a state pension also on reaching state retirement age. However, for the purposes of the examples used in this paper this will be ignored.

3. The annuity factor is calculated based on the number of years an employee is expected to live post-retirement and, if an employee has a spouse, the number of years the employee's spouse is expected to outlive the employee, thus becoming eligible for a spouse's pension. This factor is determined by mortality tables which are actuarially calculated and compiled based on historic mortality experience and also taking into account both the discount rate and expected pension increases but it may be adjusted to reflect assumptions on expected mortality experience into the future.

4. Finally, the discount rate is used to estimate the present-day value of the future liability.

Table 3 shows the comparative calculations and liabilities under the three methods of valuation assuming the base data outlined in Table $2 .{ }^{11}$

TABLE 3: COMPARATIVE RESULTS UNDER THREE VALUATION BASES

This table outlines how the pension fund liability is calculated for each valuation model - MFS, trustee and IAS 19 valuation respectively - for the base case (see Table 2). The row 'Valuation' contains the value of the pension fund liability calculated for each model.

\begin{tabular}{|c|c|c|c|}
\hline & \multicolumn{3}{|c|}{ Valuation Approach } \\
\hline & $\begin{array}{l}\text { Minimum Funding } \\
\text { Standard Valuation }\end{array}$ & $\begin{array}{c}\text { Trustees Ongoing } \\
\text { Valuation }\end{array}$ & IAS I9 Valuation \\
\hline Calculation & $\begin{array}{c}10 / 60 *(45,000 *(1.025 \wedge \\
25)) * 22.872 * 0.1547\end{array}$ & $\begin{array}{c}35 / 60 *(45,000 *(1.05 \wedge \\
25)) * 16.365 * 0.184\end{array}$ & $\begin{array}{l}10 / 35 * 35 / 60 *(45,000 \\
* 1.05 \wedge 25) * 0.256 * \\
19.336\end{array}$ \\
\hline \multirow[t]{2}{*}{ Valuation (PSL) } & $€ 50,490$ & $\begin{array}{l}€ 268,030(\mathrm{TSL}) \text { of which } \\
€ 76,580(\mathrm{PSL}) \text { relates } \\
\text { to past service and } \\
€|9|, 450 \text { relates to } \\
\text { future service }\end{array}$ & $€ \mid 25,764$ \\
\hline & Individual & Valuation Component & alculations \\
\hline Pensionable Salary & $(45,000 *(1.025 \wedge 25))$ & $(45,000 *(1.05 \wedge 25))$ & $(45,000 *(1.05 \wedge 25))$ \\
\hline Discount Factor & $0.1547^{i i}$ & $\begin{array}{l}0.184 \text { based on } \\
\text { investment growth rate } \\
(7 \%)\end{array}$ & $\begin{array}{l}0.256 \text { based on } \\
\text { corporate bond rate } \\
(5.6 \%)\end{array}$ \\
\hline
\end{tabular}


TABLE 3: (CONTINUED)

\begin{tabular}{|c|c|c|c|}
\hline & \multicolumn{3}{|c|}{ Individual Valuation Component Calculations } \\
\hline & $\begin{array}{l}\text { Minimum Funding } \\
\text { Standard Valuation }\end{array}$ & $\begin{array}{c}\text { Trustees Ongoing } \\
\text { Valuation }\end{array}$ & IAS I9 Valuation \\
\hline Annuity Factor & $\begin{array}{l}22.269 \text { (based on } \\
\text { mortality and the gap } \\
\text { between rate of pension } \\
\text { increase and prescribed } \\
\text { post-retirement discount } \\
\text { rate) }\end{array}$ & $\begin{array}{l}\text { I6.365 (based on } \\
\text { mortality and the gap } \\
\text { between rate of pension } \\
\text { increase and discount } \\
\text { rate) }\end{array}$ & $\begin{array}{l}19.336 \text { (based on } \\
\text { mortality and the gap } \\
\text { between rate of pension } \\
\text { increase and discount } \\
\text { rate) }\end{array}$ \\
\hline MVA & 1.054 & - & - \\
\hline
\end{tabular}

' Maximum pension entitlement is 1/60th of final pensionable salary for every year of completed service subject to a maximum of 40/60ths. In this example, the employee joined the scheme at age 30 and therefore has a potential maximum 35 years of completed service.

ii Discount factor (pre-retirement prescribed investment return) is 7.75 per cent; discount rate (post-retirement prescribed investment return) is 4.5 per cent. The discount rate of 0.155 is a composite rate based on the discount rates pre- and post-retirement and a market value adjustment (MVA) to reflect the gradual transfer out of equities to fixed interest stocks in the 10 years prior to normal retirement age.

TSL = Total service liability; PSL = Past service liability

The MFS valuation calculates the lump sum required to meet the future pension entitlements of the scheme member (details in Table 2) based on completed years of pensionable service to date (ten years) and current pensionable salary. Her future pension entitlement is calculated by taking the expected annual pension entitlement in the year of retirement and multiplying it by an annuity factor (taken from actuarially produced annuity tables) to reflect the expected lifespan of the member post-retirement, and the gap between any expected pension increases and any investment return on the lump sum post-retirement. The lump sum calculated as required to meet the member's entitlement is then discounted back to the present by reference to pre- and post-retirement investment growth rates prescribed by the regulator.

The trustee valuation calculates the total expected future pension entitlement of the member based on continued service up to age 65 and expected salary at the date of retirement (current salary indexed for expected annual salary increases). This figure is also increased by an annuity factor and discounted back to the present by reference to an estimated investment growth. This total expected liability is then split pro rata between completed years of pensionable service to date and future years of service to retirement.

Finally, the IAS 19 valuation is calculated as a pro rata percentage of the total expected pension entitlement calculated by reference to completed years of service to date $(10 / 35$ * 35/60). The discount rate used for this calculation is the AA corporate bond rate while the annuity rate is again based on mortality tables and the gap between the rate of pension increase and the discount rate.

Interestingly, the liability in respect of service to date is lowest under the MFS valuation, which is supportive of the submission of the Society of Actuaries in Ireland (2008) that the MFS calculation should be more conservative and a higher 
minimum funding requirement (to be achieved possibly over a longer time frame) should be introduced. The IAS 19 valuation produces the highest liability calculation; however, as the Lane Clarke \& Peacock Ireland (2009) research discussed earlier indicated, there is significant opportunity to manage this particular calculation within the range of what might be considered 'acceptable' assumption settings.

In the case of a group scheme (more than one member), the individual liabilities for each of the scheme members - whether active, deferred or pensioners - are accumulated to arrive at the total service liability for inclusion in the valuation exercise. Given the deviations in the results of the three calculations above for one individual employee, there is potential for significant differences to arise in schemes with large numbers of employees. The examples in Table 3 do not reflect the complexities of early retirement options, disability clauses or a spouse's pension (if payable), all of which would impact on the calculations although not necessarily in equal measure across all three.

In setting assumptions, the actuary can therefore be faced with a serious conflict of interest between his/her obligations to scheme trustees and scheme members and his/her desire to avoid confrontation (e.g. on contribution rates) with the sponsoring company, which may directly or indirectly be paying the actuary for his/her services and to whom the actuarial firm may be providing a range of related services. ${ }^{12}$ The trustees can likewise find themselves in difficulty with scheme members if it can be demonstrated that they presided over sustained periods of inadequate funding levels and high-risk investment strategies yet they remained aloof from the actuarial process which informs critical aspects of these decision-making processes.

There is much discussion currently as to the rigidity of the MFS and in the light of the increasing number of schemes in deficit or failing to meet the standard there is an increasing view that the standard is too high and should be lowered. As discussed earlier, the opposite view however is also held (in particular by the Society of Actuaries in Ireland (2008), i.e. that the standard is too low and should be strengthened. This view of the Society of Actuaries in Ireland is supported by the results of this paper which demonstrate that the MFS valuation always produces a lower result that the equivalent trustee valuation or IAS 19 valuation. It must also be accepted that the relative rigidity of the MFS calculations from the regulator's perspective can provide a common benchmark and a meaningful basis for comparison across pension schemes. From an individual trustee's perspective, it can provide comfort that the scope for subjectivity by the actuary in terms of the key underlying assumptions is reduced. This assurance for the trustee cannot be underestimated given the diversity of results that could conceivably arise from the three valuation approaches outlined above. However, the results of this study also highlight the importance of striving for realism in setting prescribed assumptions should the rigidity of the MFS be retained.

\section{SENSITIVITY ANALYSIS}

Having established that the three valuation models produce different results, we look at how sensitive the models are to changes in each of the key inputs. The key 
inputs are considered to be the discount rate, the rate of salary growth, the assumed rate of pension increases, the retirement age and mortality. Using our base case calculations (Table 3 ) as a base for comparison we allow each of the key assumptions to change by plus and minus 20 per cent from its base value, while holding all other inputs constant at their base values. ${ }^{13}$ We recalculate the pension fund liability to assess the effect of each percentage change in each key assumption whilst holding all other inputs constant. The results of doing so are presented in Appendices 4 through 6. Appendix 4 presents the pension fund liabilities calculated under IAS 19, Appendix 5 shows the pension fund liabilities adopting the trustee valuation approach and Appendix 6 shows the equivalent MFS calculations.

To measure the relative sensitivity of each valuation model to changes in the key inputs, we calculate the median z-score for each key input under each valuation model. The results are presented in Table 4 . We present the median, as opposed to the average, z-score since, by definition, the z-score has mean zero with a standard deviation of one. Each individual z-score is calculated as the difference between each pension fund liability calculation less the average pension fund liability calculation, divided by the standard deviation. ${ }^{14}$ We concentrate on using z-scores because other measures of dispersion/variation, e.g. the standard deviation, are sensitive to scale. The z-score is independent of scale and thus allows us to make comparisons across the key inputs, even though each is measured/constructed using different scales. By definition, z-scores are unit-free, and measure the distance of each data item (here the pension fund liability) from its average value in standard deviations. Hence they are expressed in a common scale. Since the pension fund liabilities can be above or below their mean values given a range of input values, z-scores can then be either positive or negative. For example, a z-score of $0.5(-0.5)$ suggests that the pension fund liability is half of one standard deviation above (below) the average pension fund liability. The median z-score is outlined for each key input and under each pension fund valuation method in Table 4 . The individual z-scores, calculated over the range of each key input, are outlined in Appendix 3.

Table 4 (column 4) and Appendix 4 indicate the following in relation to the sensitivity of the IAS 19 model to changes in key inputs: The pension fund liability is, as expected, a decreasing function of the discount rate, i.e. higher discount rates lead to lower pension fund liabilities. In contrast, pension fund liabilities grow with increases in expected salary and pension growth and with improvements in mortality. Pension fund liabilities increase with decreases in the expected age of retirement and vice versa. For example, for an individual retiring at 71.5 years of age, and holding all other inputs constant at their base values, the pension fund liability is $€ 102,803$, compared to the base case of $€ 125,764$ where it is assumed that the individual retires much earlier at 65 years of age. In contrast, and as expected, pension fund liabilities increase with improving mortality. By way of example, consider an individual who lives to 103.95 years of age. His/her pension fund liability is calculated as $€ 147,677$ or 1.17 times (see Appendix 4, column labelled 'Ratio L/Base') the base case (i.e. $147,677 / 125,764=1.17$ ). For an individual who lives to 80.325 years of age, the pension fund liability is much lower at $€ 78,836$ or just 63 per cent of that of the base case (i.e. $\left.(78,836 / 125,764){ }^{*} 100\right)$. In terms of relative sensitivity, the IAS 19 model is most sensitive to changes in the age of mortality (standard deviation is 
36,235 , and z-score is 0.17 ), followed closely by changes in the discount rate (standard deviation is 35,950 , with a median $\mathrm{z}$-score of 0.13 ). The pension fund liability under IAS 19 is less sensitive to changes in salary growth (standard deviation is 20,671, with a median z-score of 0.07 ) and the retirement age (while the standard deviation is high $(30,335)$, the median z-score is just 0.05$)$. Finally, under IAS 19 , the pension fund liability is least sensitive to the assumed rate of pension increase, since the median $\mathrm{z}$-score is just 0.03 .

\section{TABLE 4: SENSITIVITY OF PENSION FUND LIABILITYTO CHANGES IN KEY INPUTS}

This table displays the median z-score of the pension fund liability calculated under the IAS I9, MFS and trustee models, respectively, assuming a range of values for each key input between plus and minus $20 \%$ of their base value, with all other inputs held constant at their base values. The key inputs are the discount rate, salary growth, pension increases, retirement age and mortality, and their base values are $5.6 \%$ (7\% under ongoing trustee valuation, and $7.75 \%$ (pre-retirement discount rate) and $4.50 \%$ (post-retirement discount rate) under minimum funding valuation), 5\%, 2.5\%, 65 and 94.5 years of age, respectively. The individual $z$-scores are calculated as $\left(z=\frac{x-\bar{x}}{s}\right)$, where $x$ is the pension fund liability, $x$-bar is the average pension fund liability, and $s$ is the standard deviation of the pension fund liability. In the bottom rows of Table 4, we present the sum (average) of the absolute values of the (median) z-scores for each valuation method. In the remaining column of Table 4, we present the sum (average) of the absolute values of the (median) z-scores for each key input.

\begin{tabular}{|c|c|c|c|c|}
\hline \multirow[b]{2}{*}{ Key Input } & \multicolumn{3}{|c|}{ Pension Fund Liabilities Valuation Method } & \multirow[b]{2}{*}{$\begin{array}{c}\text { Sum (Average) of } \\
\text { Absolute z-Scores by } \\
\text { Input }\end{array}$} \\
\hline & $\begin{array}{l}\text { Minimum } \\
\text { Funding } \\
\text { Valuation }\end{array}$ & $\begin{array}{l}\text { Trustees } \\
\text { Ongoing } \\
\text { Valuation }\end{array}$ & IAS I 9 Valuation & \\
\hline \multicolumn{5}{|c|}{ Median z-Score } \\
\hline Discount Rate & $(0.15)$ & $(0.16)$ & $(0.13)$ & $0.43(0.143)$ \\
\hline Salary Growth & - & $(0.07)$ & $(0.07)$ & $0.14(0.070)$ \\
\hline Pension Increases & $(0.03)$ & $(0.04)$ & 0.03 & $0.10(0.033)$ \\
\hline Retirement Age & $(0.22)$ & $(0.03)$ & $(0.05)$ & $0.30(0.100)$ \\
\hline Mortality & $(0.11)$ & $(0.23)$ & $(0.17)$ & $0.51(0.170)$ \\
\hline \multicolumn{5}{|c|}{$\begin{array}{c}\text { Sum (Average) of Absolute z-Scores by } \\
\text { Valuation Method }\end{array}$} \\
\hline & $\begin{array}{l}0.51 \\
(0.1275) \\
\end{array}$ & $\begin{array}{l}0.53 \\
(0.106) \\
\end{array}$ & $\begin{array}{l}0.45 \\
(0.090) \\
\end{array}$ & \\
\hline \multicolumn{5}{|c|}{$\begin{array}{c}\text { Sum (Average) of Absolute z-Scores by } \\
\text { Valuation Method (Excluding Salary Growth) }\end{array}$} \\
\hline & $\begin{array}{l}0.51 \\
(0.1275)\end{array}$ & $\begin{array}{l}0.46 \\
(0.115)\end{array}$ & $\begin{array}{l}0.38 \\
(0.095)\end{array}$ & \\
\hline
\end{tabular}

Table 4 (column 3) and Appendix 5 present the same analysis for pension fund liabilities calculated using the trustee model. The trustee model is also most sensitive to the age of mortality (median z-score is 0.23 ), followed by the discount rate (median z-score is 0.16). It is less sensitive to changes in salary growth (median $\mathrm{z}$-score is 0.07) and the rate of pension increases (median z-score is 0.04), and is least sensitive to the assumed retirement age (median z-score is 0.03 ). 
Table 4 (column 2) and Appendix 6 present the equivalent results for pension fund liabilities calculated under the MFS model. In contrast to the IAS 19 and trustee models, the MFS is most sensitive to changes in the assumed retirement age (the median z-score for the retirement age is 0.22 ), followed by the discount rate (median z-score is 0.15 ), the age of mortality (median z-score is 0.11 ) and, finally, pension increases (median z-score is 0.03 ).

Our findings discussed thus far highlight how changes in the key inputs affect the pension fund liabilities differently across the different valuation models. In terms of relative sensitivity, changes in the discount rate have greatest relative impact on the trustee model followed by the MFS and the IAS 19 models respectively (compare (0.16) under trustee to (0.15) under MFS and (0.13) under IAS 19). The effect of changes in salary growth (and pension fund increases) on the pension fund liability is largely the same across the different valuation models. Only the MFS valuation is largely affected by the age of retirement (compare (0.22) under MFS to $(0.03)$ and (0.05) under trustee and IAS 19, respectively). All three models are sensitive to changes in mortality assumptions, but the greatest sensitivity arises under trustee valuation (compare (0.23) to (0.11) under MFS and (0.17) under IAS 19).

In column 5 of Table 4, we assess across the different valuation methods which key input has greatest impact across the three models. To do this, we sum the absolute values of the (median) z-scores for each input across the three models. The key input with the largest sum of absolute median z-scores is the input which has the greatest relative impact across the three models. Column 5 of Table 4 suggests that across the three different valuation methods, the pension fund liability is most sensitive to the age of mortality (sum of median absolute z-scores is 0.51 , with an average of 0.17 ), followed by the discount rate (sum of median absolute z-scores is 0.43 , with an average of 0.143 ). The pension fund liability is least sensitive to the assumed rate of salary (sum of median absolute z-scores is 0.14) and pension growth rate (sum of median absolute z-scores is 0.10 ).

In the remaining rows of Table 4 (rows 9 to 12), we assess the relative sensitivity of each of the models. To do so, we sum the absolute value of the median z-scores, not across the key inputs but for each model, and compare the three results. The model most sensitive to changes in the key inputs will display the largest (absolute) aggregated (median) z-score. Our findings suggest that the MFS model is most sensitive (sum of absolute median z-scores is $0.51(0.15+0.03+0.22+0.11$ ) with an average $z$-score of 0.1275 , compared to 0.46 (with an average $z$-score of 0.115 ) for the trustee model $(0.16+0.04+0.03+0.23)$, and 0.38 under IAS $19(0.13+0.03+0.05+$ 0.17 ) (with an average z-score of 0.095).

In Table 5, we calculate the average percentage (\%) change in the pension fund liability assuming a one-unit change in each key input. ${ }^{15}$ This exercise is performed for all three models. Coughlan, Epstein, Ong, Sinha, Hevia-Portocarrero, Gingrich, Khalaf-Allah and Joseph (2007) and Blake, Khorasanee, Pickles and Tyrrall (2008) show that the pension fund liability changes on average between 3 and 4 per cent when they assume life-expectancy changes by one year. Along similar lines, May, Querner and Schmitz (2005) and Gohdes and Baach (2004) show that a 1 percentagepoint change in the discount rate (for example between 4 and 5 per cent) changes the value of the pension fund liability on average by 15 per cent. Our findings suggest 
that the Irish valuation models are just as sensitive to changes in the assumed age of mortality (the average percentage change in the pension fund liability is 2.91 per cent), but more sensitive to changes in the discount rate (the average percentage change in the pension fund liability is 35.21 per cent).

\section{TABLE 5: AVERAGE PERCENTAGE CHANGE IN PENSION FUND LIABILITY} ASSUMING A I UNIT CHANGE IN EACH INPUT

In this table we calculate the average percentage (\%) change in pension fund liability assuming a I unit change in each key input. Discount rate, salary growth and pension increases range from I to 12\%. The retirement age ranges from 60 to 70 years of age, and mortality from 80 to 100 years of age. In the case of minimum fund valuation, the pre-retirement (post-retirement) discount rate ranges from $4.25 \%$ to $16.25 \%$ ( $1 \%$ to $12 \%)$.

\begin{tabular}{lcccc}
\hline & \multicolumn{4}{c}{ Pension Fund Liabilities Valuation Method } \\
& $\begin{array}{c}\text { Minimum Funding } \\
\text { Valuation }\end{array}$ & $\begin{array}{c}\text { Trustees Ongoing } \\
\text { Valuation }\end{array}$ & IAS I9 Valuation & Average \\
\hline Discount Rate & $34.75 \%$ & $35.44 \%$ & $35.44 \%$ & $35.21 \%$ \\
Salary Growth & $0.00 \%$ & $23.50 \%$ & $23.50 \%$ & $15.67 \%$ \\
Pension Increases & $15.48 \%$ & $12.44 \%$ & $14.80 \%$ & $14.24 \%$ \\
Retirement Age & $7.37 \%$ & $3.60 \%$ & $2.72 \%$ & $4.56 \%$ \\
Mortality & $3.35 \%$ & $2.46 \%$ & $2.93 \%$ & $2.91 \%$ \\
\hline
\end{tabular}

\section{PRACTICAL IMPLICATIONS FOR SCHEME GOVERNANCE}

The deviation in valuation results across the three valuation models and the inconsistencies demonstrated by the sensitivity analysis in terms of how the individual models are impacted by changes in constituent key inputs are interesting for a variety of reasons. They highlight the challenge to ensure that every care is taken to ensure that actuarial assumptions adopted on key inputs are based on sound principles. It could be argued that they provide opportunities to manage a reported valuation result. They certainly pose challenges for trustees charged with governance of pension schemes in understanding the actuarial process and the impact of what might seem small percentage changes in certain assumptions on the required funding rate or the reported scheme surplus/deficit. Tax-incentivised pension schemes do not have a long history in Ireland (dating back only to the 1960s). It is only in the relatively recent past that pension scheme members and trustees have had to contend with scheme deficits and schemes failing to deliver on pension promises. To date there has not been any case of legal action being taken against scheme trustees for breach of pension promises due to inadequate funding because of over-aggressive actuarial assumption setting. This may, however, be due to individual members being without the means to take such a case rather than their being of the view that they do not have a grievance. In any event, recent pronouncements by the Pensions Board (2009) would seem to suggest that inadequate funding due to aggressive assumption setting is not only possible as our paper demonstrates but is, in fact, a harsh reality notwithstanding the absence of litigation. 


\section{CONCLUSIONS}

The assessment of pension fund liabilities is a complex exercise exacerbated by the potential for different acceptable valuations for one scheme and (as evidenced by this paper) inconsistencies in the sensitivity across the different valuation frameworks to changes in underlying valuation assumptions. Given that there is ongoing robust debate on optimal valuation approaches within the actuarial valuation itself, and there are external factors, such as discount rates significantly impacting on pension schemes' reported results, the importance of regulation to monitor and control the subjectivity of and increase the transparency of the actuarial valuation process is paramount.

The high level of estimation required in setting certain key assumptions and differences in the relative sensitivity of reported results to changes in those assumptions has implications for scheme governance, in that it requires those charged with scheme governance to understand the key assumptions driving the result rather than just accept the result as the only possible correct answer. It is of particular relevance to trustees who have ultimate responsibility for scheme governance. If trustees do not understand the potential impact of changes in certain key assumptions on a valuation result, they cannot contribute fully to an informed debate on appropriate contribution rates, investment strategies, discretionary bonuses and so on, and accordingly cannot discharge their trustee obligations entirely. This necessitates greater transparency on the acceptable 'range' for each assumption, where the adopted assumption fits within that range and what would be the impact of a more prudent/optimistic approach. It also makes it necessary for all trustees to have quite specialist knowledge on the alternate methods of valuations and the reasons for the significant differences that can arise between these valuations.

The accounts preparation and audit exercise coupled with the actuarial valuation processes are relied upon by all scheme stakeholders - trustees, members and employers alike - to gain assurances in relation to the financial health of a pension scheme, or at least to be presented with up-to-date facts which will facilitate planning for remedial action. In the first instance, members will assume that trustees are adequately informed so that they (the members) can in turn be adequately informed. Assumptions underpinning the actuarial valuation exercise are critical to this monitoring process. It is not appropriate that these decisions be entirely delegated to the actuarial profession. Trustees cannot defray their responsibilities by remaining largely aloof from the actuarial exercise and relying on their own assumption that the 'expert', i.e. the actuary, is always right

This research highlights, rather than provides any clear solution to, the complexities of pension scheme valuations. A streamlined, simplified and transparent process acceptable to all stakeholders would require multi-faceted research carried out in conjunction with the overall development of pension policy. In the meantime however, while the minimum funding standard valuation is being heavily criticised, one advantage it can boast is that it is the least subjective of all three valuation approaches and as such provides a common benchmark against which the financial health of pension schemes can be assessed. It reduces the potential conflicts of interest for the scheme actuary and agency issues arising from the relationships between the trustees, 
the sponsoring company and the actuary. While regulators are being forced to relax on the time period given to schemes to bring their funding back within the minimum limits, they should be slow to depart from the policy of a standardised valuation so long as realism in setting prescribed assumptions is considered a priority.

\section{NOTES}

Most schemes are structured as trusts in order to avail of favourable treatment.

2 Goode (1993, para. 4.9.7.) states that trustees must 'exercise, in relation to all matters affecting the fund, the same degree of care and diligence as an ordinary prudent person would exercise in dealing with property of another for whom the person felt morally bound to provide and to use such additional knowledge and skill as the trustee possesses or ought to possess by reason of the trustees' profession, business or calling.

3 Scott $v$ National Trust for Places of Historic Interest or Natural Beauty (1998), cited in Delaney (2007).

4 In the Irish context, Connell (2007) discusses the costs and sustainability of different proposals for pension provision, and refers to the plethora of assumptions which underpin each different proposal/model. Lane Clarke \& Peacock Ireland (2009) noted that from the IAS 19 valuations of 29 Irish schemes reviewed, widely varying assumptions were used in key areas across the schemes. Life expectancy assumptions adapted by the schemes surveyed ranged from 83.5 years to 87.1 years for a male and 86 years to over 90 years for a female. Discount rate assumptions (based on 'high quality' corporate bond rates) ranged from under 5.6 per cent to 6.5 per cent; inflation assumptions ranged from 1.75 per cent to 2.5 per cent and expected return on equities ranged from 7 per cent to 9 per cent.

5 Attain Consulting (2009) considers the impact of the discount rate, but no other key inputs, used in the actuarial valuation calculation of the deficits of pension schemes of companies quoted on the Irish Stock Exchange. Defined benefit schemes of certain public sector organisations are exempt from the funding standard.

7 At the time of writing, the most recent version of ASP PEN 2 is effective May 2012, while the most recent version of ASP PEN 3 is effective January 2013.

8 The most recent version.

9 A z-score is a statistical measurement of a score's relationship to the mean in a group of scores. A z-score of 0 means that the score is the same as the mean.

10 Revenue approval is necessary if the pension scheme is to benefit from the favourable tax treatment available to Revenue-approved pension schemes.

11 The exact formulae used to calculate the pension fund liabilities under MFS, ongoing trustees and IAS 19 are presented in Appendix 1. Appendix 2 contains a description of the variables used in the calculation of the pension fund liabilities.

12 Many of the actuarial firms also provide a range of related services, e.g. consulting, outsourcing and investment services.

13 The range of each input is subdivided into four equally spaced values, either side of the base case. For example, in the case of IAS 19 and the discount rate, the discount rate ranges from 4.48 to 6.72 per cent, with a base value of 5.60 per cent. We evaluate the pension fund liability under IAS 19 (with all other inputs held at their base values), using intervals of 0.28 for the discount rate over the range of 4.48 to 6.72 per cent (i.e. (6.72 $4.48) / 8$ is 0.28 ). Hence, the pension fund liability is evaluated where the discount rate is $4.48,4.76,5.04,5.32$, $5.60,5.88,6.16,6.44$, and 6.72 . Since there are four equally spaced values of the discount rate (and all other key inputs) either side of the base case (and thus nine in total), the median $z$-score presented in Table 4 is the $\mathrm{z}$-score for the base case of each input (i.e. the fifth value). The $\mathrm{z}$-scores calculated across the range of $\mathrm{z}$-scores are presented in Appendix 3.

14 That is, the $\mathrm{z}$-score is calculated as $\left(\mathrm{z}=\frac{\mathrm{x}-\overline{\mathrm{x}}}{\mathrm{s}}\right)$, where $x$ is the pension fund liability, $x$-bar is the average pension fund liability, and $s$ is the standard deviation pension fund liability. For example, if we assume a discount rate of 4.48 per cent, the pension fund liability calculated under IAS 19 is $€ 189,589$, with an average (standard deviation) pension fund liability (over a range of discount rates from 4.48 to 6.72 per cent) of $€ 130,429(35,950)$. The $\mathrm{z}$-score is then calculated as $\left(\mathrm{z}=\frac{189,589-130,429}{35,950}\right)=1.65$ (See Appendix 3).

15 Discount rate, salary growth and pension increases range from 1 to 12 per cent. The retirement age ranges from 60 to 70 years of age, and mortality from 80 to 100 years of age. In the case of minimum fund valuation, the preretirement (post-retirement) discount rate ranges from 4.25 per cent to 16.25 per cent ( 1 per cent to 12 per cent). 


\section{APPENDIX I: CALCULATION OF PENSION FUND LIABILITIES UNDER MINIMUM FUND STANDARD, ONGOING TRUSTEE AND IAS I 9 VALUATIONS}

The exact formula used to calculate the pension fund liability under the minimum funding standard valuation is presented as Equation (I), where AF and AR are the annuity factor and annuity rate respectively. All variables are defined in Appendix 2.

$$
\begin{aligned}
& \mathrm{TSL}=\left(\frac{\mathrm{m}}{60}\right) *\left(\mathrm{CS} *(1+\mathrm{IR})^{\mathrm{y}}\right) *\left(\frac{1}{\left(1+\mathrm{r}_{\text {pre }}\right)^{\mathrm{y}}}\right) *\left(\frac{\left(1-\left(\frac{1}{(1+\mathrm{AF})}\right)\right)^{\mathrm{P}}}{\mathrm{AF}}\right) * \mathrm{MVA} \\
& \mathrm{AF}=\left(1-\left(\frac{1}{1+\mathrm{AR}}\right)\right)^{\frac{\mathrm{P}}{\mathrm{AR}}}, \quad \mathrm{AR}=\left(\frac{\left(1+\mathrm{r}_{\text {post }}\right)}{1+\mathrm{PI}}\right)-1
\end{aligned}
$$

The ongoing trustee valuation calculates the total expected future pension entitlement of the member according to Equations 2 and 3. The expected future pension entitlement calculation is based on continued service up to age 65 and based on an expected salary at the date of retirement (current salary indexed for expected annual salary increases). This figure is also increased by an annuity factor and discounted back to the present by reference to an estimated investment growth. This total expected liability is then split pro rata between completed years of pensionable service to date and future years of service to retirement.

$\mathrm{TSL}=\left(\frac{\mathrm{n}}{60}\right) *\left(\mathrm{CS} *(1+\mathrm{SG})^{\mathrm{y}}\right) *\left(\frac{1}{(1+\mathrm{r})^{\mathrm{y}}}\right) *\left(\frac{\left(1-\left(\frac{1}{(1+\mathrm{AF})}\right)\right)^{\mathrm{P}}}{\mathrm{AF}}\right)$

$\mathrm{PSL}=\mathrm{TSL} *\left(\frac{\mathrm{m}}{\mathrm{n}}\right)$

$\mathrm{AF}=\left(1-\left(\frac{1}{1+\mathrm{AR}}\right)\right)^{\frac{\mathrm{P}}{\mathrm{AR}}}, \quad \mathrm{AR}=\left(\frac{(1+\mathrm{r})}{(1+\mathrm{PI})}\right)-1$

Finally, the IAS 19 valuation is calculated as a pro rata percentage of the total expected pension entitlement calculated by reference to completed years of service to date (10/35*35/60), according to Equation (4). The discount rate used for this calculation is the AA corporate bond rate while the annuity rate is again based on mortality tables and the gap between the rate of pension increase and the discount rate.

$$
\begin{aligned}
& \mathrm{TSL}=\left(\frac{\mathrm{m}}{\mathrm{n}}\right) *\left(\frac{\mathrm{n}}{60}\right) *\left(\mathrm{CS} *(1+\mathrm{SG})^{\mathrm{y}}\right) *\left(\frac{1}{(1+\mathrm{CBR})^{\mathrm{y}}}\right) *\left(\frac{\left(1-\left(\frac{1}{(1+\mathrm{AF})}\right)\right)^{\mathrm{P}}}{\mathrm{AF}}\right) \\
& \mathrm{AF}=\left(1-\left(\frac{1}{1+\mathrm{AR}}\right)\right)^{\frac{\mathrm{P}}{\mathrm{AR}}}, \quad \mathrm{AR}=\left(\frac{(1+\mathrm{r})}{(1+\mathrm{PI})}\right)-1
\end{aligned}
$$




\section{APPENDIX 2: VARIABLE DESCRIPTIONS}

\begin{tabular}{ll}
\hline Variable & Description \\
\hline TSL & Total service liability \\
PSL & Past service liability \\
$\mathrm{m}$ & The number of years of pensionable service completed to date \\
$\mathrm{CS}$ & Current salary \\
$\mathrm{IR}$ & Expected rate of inflation \\
$y$ & Number of years to retirement \\
$\mathrm{r}_{\text {pre }}$ & Pre-retirement discount rate \\
$\mathrm{r}_{\text {post }}$ & Post-retirement discount rate \\
$\mathrm{P}$ & Expected lifespan post-retirement \\
AF & Annuity factor \\
AR & Annuity rate \\
MVA & Adjustment to allow for reduction in the pre-retirement discount rate to the post- \\
& retirement discount rate on a uniform basis over the I0 years immediately prior to \\
& normal retirement age. MVA factors are prescribed by the Society of Actuaries in \\
$\mathrm{n}$ & Ireland \\
$\mathrm{CBR}$ & Discount rate \\
& Salary growth \\
& The number of pensionable years \\
& AA corporate bond rate \\
\hline
\end{tabular}

\section{APPENDIX 3: INDIVIDUAL AND MEDIAN Z-SCORES}

This table displays the value of the z-score of each individual pension fund liability calculated under IAS 19, minimum funding standard valuation and wind-up valuation, respectively, assuming that each input ranges between plus and minus $20 \%$ of their base value, while all other inputs are held constant at their base values. The key inputs are the discount rate, salary growth, pension increases, retirement age and mortality. Their base values are 5.6\% (7\% under ongoing trustee valuation, and $7.75 \%$ (pre-retirement) and $4.50 \%$ (post-retirement) under minimum funding valuation), 5\%, 2.50\%, 65 and 94.5 years of age, respectively. The individual z-scores are calculated as follows $\left(z=\frac{x-\bar{x}}{s}\right)$, where $x$ is the pension fund liability, $x$-bar is the average pension fund liability, and $s$ is the standard deviation of the pension fund liability.

\begin{tabular}{|c|c|c|c|c|c|c|c|c|c|}
\hline Individu & and $\mathrm{Me}$ & dian z- & cores of & the $\mathrm{Pe}$ & sion Fu & Liabilit & s Calcu & ated un & er IAS I9 \\
\hline Discou & t Rate & Salary & Growth & $\begin{array}{l}\text { Pe } \\
\text { Inc }\end{array}$ & $\begin{array}{l}\text { sion } \\
\text { ease }\end{array}$ & Mor & lity & Retire & ent Age \\
\hline Value & z-Score & Value & z-Score & Value & z-Score & Value & z-Score & Value & z-Score \\
\hline 4.48 & 1.65 & 4.00 & $(1.36)$ & 2.000 & 1.42 & 75.600 & $(1.70)$ & 52.00 & $(1.39)$ \\
\hline 4.76 & 1.13 & 4.25 & $(1.07)$ & 2.125 & 1.09 & 80.325 & $(I .13)$ & 55.25 & $(1.07)$ \\
\hline 5.04 & 0.66 & 4.50 & $(0.75)$ & 2.250 & 0.74 & 85.050 & $(0.64)$ & 58.50 & $(0.75)$ \\
\hline 5.32 & 0.24 & 4.75 & $(0.42)$ & 2.375 & 0.39 & 89.775 & $(0.2 I)$ & 61.75 & $(0.4 I)$ \\
\hline 5.60 & $(0.13)$ & 5.00 & $(0.07)$ & 2.500 & 0.03 & 94.500 & 0.17 & 65.00 & $(0.05)$ \\
\hline
\end{tabular}


APPENDIX 3: (CONTINUED)

\begin{tabular}{cccccccccc}
\hline \multicolumn{2}{c}{ Discount Rate } & \multicolumn{2}{c}{ Salary Growth } & \multicolumn{2}{c}{$\begin{array}{c}\text { Pension } \\
\text { Increase }\end{array}$} & \multicolumn{2}{c}{ Mortality } & \multicolumn{2}{c}{ Retirement Age } \\
Value & z-Score & Value & z-Score & Value & z-Score & Value & z-Score & Value & z-Score \\
\hline 5.88 & $(0.46)$ & 5.25 & 0.30 & 2.625 & $(0.34)$ & 99.225 & 0.49 & 68.25 & 0.32 \\
6.16 & $(0.77)$ & 5.50 & 0.70 & 2.750 & $(0.72)$ & 103.950 & 0.77 & 71.50 & 0.70 \\
6.44 & $(1.04)$ & 5.75 & 1.12 & 2.875 & $(1.10)$ & 108.675 & 1.01 & 74.75 & 1.11 \\
6.72 & $(1.28)$ & 6.00 & 1.56 & 3.000 & $(1.50)$ & 113.400 & 1.23 & 78.00 & 1.54 \\
Median & $(0.13)$ & & $(0.07)$ & & 0.03 & & 0.17 & & $(0.05)$ \\
\hline
\end{tabular}

Individual and Median z-Scores of the Pension Fund Liabilities Calculated under Ongoing Trustee Valuation

\begin{tabular}{|c|c|c|c|c|c|c|c|c|c|}
\hline \multicolumn{2}{|c|}{ Discount Rate } & \multicolumn{2}{|c|}{ Salary Growth } & \multicolumn{2}{|c|}{$\begin{array}{l}\text { Pension } \\
\text { Increase }\end{array}$} & \multicolumn{2}{|c|}{ Mortality } & \multicolumn{2}{|c|}{ Retirement Age } \\
\hline Value & z-Score & Value & z-Score & Value & z-Score & Value & z-Score & Value & z-Score \\
\hline 5.60 & 1.68 & 4.00 & $(1.36)$ & 2.000 & $(2.15)$ & 75.600 & $(1.80)$ & 52.00 & 1.51 \\
\hline 5.95 & 1.13 & 4.25 & (I.07) & 2.125 & $(1.64)$ & 80.325 & (I.13) & 55.25 & 1.10 \\
\hline 6.30 & 0.64 & 4.50 & $(0.75)$ & 2.250 & $(1.12)$ & 85.050 & $(0.58)$ & 58.50 & 0.71 \\
\hline 6.65 & 0.22 & 4.75 & $(0.42)$ & 2.375 & $(0.58)$ & 89.775 & $(0.13)$ & 61.75 & 0.34 \\
\hline 7.00 & $(0.16)$ & 5.00 & $(0.07)$ & 2.500 & $(0.04)$ & 94.500 & 0.23 & 65.00 & $(0.03)$ \\
\hline 7.35 & $(0.48)$ & 5.25 & 0.30 & 2.625 & 0.52 & 99.225 & 0.53 & 68.25 & $(0.39)$ \\
\hline 7.70 & $(0.77)$ & 5.50 & 0.70 & 2.750 & 1.09 & 103.950 & 0.77 & 71.50 & $(0.74)$ \\
\hline 8.05 & $(\mathrm{I} .02)$ & 5.75 & 1.12 & 2.875 & 1.67 & 108.675 & 0.97 & 74.75 & $(1.08)$ \\
\hline 8.40 & $(1.24)$ & 6.00 & 1.56 & 3.000 & 2.26 & I I 3.400 & 1.13 & 78.00 & $(1.42)$ \\
\hline Median & $(0.16)$ & & $(0.07)$ & & $(0.04)$ & & 0.23 & & $(0.03)$ \\
\hline
\end{tabular}

Individual and Median z-Scores of the Pension Fund Liabilities Calculated under Minimum Funding Valuation

\begin{tabular}{|c|c|c|c|c|c|c|c|c|c|}
\hline \multicolumn{2}{|c|}{ Discount Rate } & \multicolumn{2}{|c|}{ Salary Growth } & \multicolumn{2}{|c|}{$\begin{array}{l}\text { Pension } \\
\text { Increase }\end{array}$} & \multicolumn{2}{|c|}{ Mortality } & \multicolumn{2}{|c|}{ Retirement Age } \\
\hline $\begin{array}{c}\text { Value (Pre/ } \\
\text { Post) }\end{array}$ & z-Score & Value & z-Score & Value & z-Score & Value & z-Score & Value & z-Score \\
\hline $6.20 / 3.60$ & 1.68 & 4.00 & - & 2.000 & $(1.42)$ & 75.600 & $(1.62)$ & 52.00 & 1.77 \\
\hline $6.59 / 3.83$ & 1.12 & 4.25 & - & 2.125 & (1.09) & 80.325 & $(1.12)$ & 55.25 & 1.13 \\
\hline $6.98 / 4.05$ & 0.64 & 4.50 & - & 2.250 & $(0.74)$ & 85.050 & $(0.67)$ & 58.50 & 0.60 \\
\hline $7.36 / 4.28$ & 0.23 & 4.75 & - & 2.375 & $(0.39)$ & 89.775 & $(0.26)$ & 61.75 & 0.15 \\
\hline $7.75 / 4.50$ & $(0.15)$ & 5.00 & - & 2.500 & $(0.03)$ & 94.500 & 0.11 & 65.00 & $(0.22)$ \\
\hline $8.14 / 4.73$ & $(0.48)$ & 5.25 & - & 2.625 & 0.34 & 99.225 & 0.45 & 68.25 & $(0.52)$ \\
\hline $8.53 / 4.95$ & $(0.77)$ & 5.50 & - & 2.750 & 0.72 & 103.950 & 0.76 & 71.50 & $(0.77)$ \\
\hline $8.92 / 5.18$ & $(1.03)$ & 5.75 & - & 2.875 & 1.10 & 108.675 & 1.05 & 74.75 & $(0.98)$ \\
\hline $9.30 / 5.40$ & $(1.25)$ & 6.00 & - & 3.000 & 1.50 & 113.400 & 1.31 & 78.00 & $(1.15)$ \\
\hline Median & $(0.15)$ & & - & & $(0.03)$ & & 0.11 & & $(0.22)$ \\
\hline
\end{tabular}




\section{APPENDIX 4: IAS I 9 ACCOUNTING VALUATION}

This table displays the value of the pension fund liability calculated under IAS 19 assuming that each input ranges between plus and minus $20 \%$ of their base value, while all other inputs are held constant at their base values. The key inputs are the discount rate, salary growth, pension increases, retirement age and mortality. Their base values are 5.6\%, 5\%, 2.50\%, 65 and 94.5 years of age, respectively. The average and standard deviation pension fund liability and the ratio of the pension fund liability to the base case (L/Base) are reported in the remaining rows.

\begin{tabular}{|c|c|c|c|c|c|c|c|c|}
\hline \multicolumn{3}{|c|}{ Discount Rate (DR) } & \multicolumn{3}{|c|}{ Salary Growth (SG) } & \multicolumn{3}{|c|}{ Pension Increase (PI) } \\
\hline$D R$ & Liability (L) & Ratio (L/Base) & SG & Liability (L) & Ratio (L/Base) & PI & Liability (L) & Ratio (L/Base) \\
\hline 4.48 & 189,589 & 1.51 & 4.00 & 99,005 & 0.79 & 2.000 & 118,048 & 0.94 \\
\hline 4.76 & 170,900 & 1.36 & 4.25 & 105,130 & 0.84 & 2.125 & 119,916 & 0.95 \\
\hline 5.04 & 154,174 & 1.23 & 4.50 & 111,617 & 0.89 & 2.250 & $|2|, 824$ & 0.97 \\
\hline 5.32 & 139,193 & 1.11 & 4.75 & II 8,488 & 0.94 & 2.375 & 123,773 & 0.98 \\
\hline 5.60 & 125,764 & 1.00 & 5.00 & 125,764 & 1.00 & 2.500 & 125,764 & 1.00 \\
\hline 5.88 & 113,717 & 0.90 & 5.25 & 133,468 & 1.06 & 2.625 & 127,798 & 1.02 \\
\hline 6.16 & $|02,90|$ & 0.82 & 5.50 & $|4|, 624$ & 1.13 & 2.750 & 129,875 & 1.03 \\
\hline 6.44 & 93,183 & 0.74 & 5.75 & 150,257 & 1.19 & 2.875 & 131,998 & 1.05 \\
\hline 6.72 & 84,444 & 0.67 & 6.00 & 159,394 & 1.27 & 3.000 & 134,166 & 1.07 \\
\hline Average & 130,429 & 1.04 & & 127,194 & 1.01 & & 125,907 & 1.00 \\
\hline \multirow[t]{14}{*}{ Std. Dev. } & 35,950 & 0.29 & & 20,671 & 0.16 & & 5,517 & 0.04 \\
\hline & \multicolumn{4}{|c|}{ Mortality } & \multicolumn{4}{|c|}{ Retirement Age } \\
\hline & Mortality & Liability (L) & \multicolumn{2}{|c|}{ Ratio (L/Base) } & Retirement $L$ & Liability (L) & \multicolumn{2}{|c|}{ Ratio (L/Base) } \\
\hline & 75.600 & 58,242 & \multicolumn{2}{|c|}{0.46} & 52.00 & 166,315 & \multicolumn{2}{|c|}{1.32} \\
\hline & 80.325 & 78,836 & \multicolumn{2}{|c|}{0.63} & 55.25 & 156,748 & \multicolumn{2}{|c|}{1.25} \\
\hline & 85.050 & 96,725 & \multicolumn{2}{|c|}{0.77} & 58.50 & 146,825 & \multicolumn{2}{|c|}{1.17} \\
\hline & 89.775 & II 2,265 & \multicolumn{2}{|c|}{0.89} & 61.75 & 136,510 & \multicolumn{2}{|c|}{1.09} \\
\hline & 94.500 & 125,764 & \multicolumn{2}{|c|}{1.00} & 65.00 & 125,764 & \multicolumn{2}{|c|}{1.00} \\
\hline & 99.225 & $|37,49|$ & \multicolumn{2}{|c|}{1.09} & 68.25 & II 4,544 & \multicolumn{2}{|c|}{0.91} \\
\hline & 103.950 & 147,677 & \multicolumn{2}{|c|}{1.17} & 71.50 & 102,803 & \multicolumn{2}{|c|}{0.82} \\
\hline & 108.675 & 156,526 & \multicolumn{2}{|c|}{1.24} & 74.75 & 90,493 & \multicolumn{2}{|c|}{0.72} \\
\hline & 113.400 & 164,213 & \multicolumn{2}{|c|}{1.31} & 78.00 & 77,559 & \multicolumn{2}{|c|}{0.62} \\
\hline & Average & 119,749 & \multicolumn{2}{|c|}{0.95} & & 124,173 & \multicolumn{2}{|c|}{0.99} \\
\hline & Std. Dev. & 36,235 & \multicolumn{2}{|c|}{0.29} & & 30,335 & \multicolumn{2}{|c|}{0.24} \\
\hline
\end{tabular}




\section{APPENDIX 5: ONGOING TRUSTEE VALUATION}

This table displays the value of the pension fund liability calculated under the ongoing trustee valuation assuming that each input ranges between plus and minus $20 \%$ of their base value, while all other inputs are held constant at their base values. The key inputs are the discount rate, salary growth, pension increases, retirement age and mortality. Their base values are 7\%, 5\%, 2.50\%, 65 and 94.5 years of age, respectively. The average and standard deviation pension fund liability and the ratio of the pension fund liability to the base case (L/Base) are reported in the remaining rows.

\begin{tabular}{ccccccccc}
\hline \multicolumn{3}{c}{ Discount Rate (DR) } & \multicolumn{3}{c}{ Salary Growth (SG) } & \multicolumn{3}{c}{ Pension Increase (PI) } \\
$D R$ & Liability (L) Ratio (L/Base) & SG & Liability (L) & Ratio (L/Base) & PI & \multicolumn{2}{c}{ Liability (L) } & Ratio (L/Base) \\
\hline 5.60 & 125,764 & 1.64 & 4.00 & 60,286 & 0.79 & 2.000 & 72,196 & 0.94 \\
5.95 & 110,903 & 1.45 & 4.25 & 64,016 & 0.84 & 2.125 & 73,259 & 0.96 \\
6.30 & 97,912 & 1.28 & 4.50 & 67,966 & 0.89 & 2.250 & 74,344 & 0.97 \\
6.65 & 86,543 & 1.13 & 4.75 & 72,150 & 0.94 & 2.375 & 75,451 & 0.99 \\
7.00 & 76,580 & 1.00 & 5.00 & 76,580 & 1.00 & 2.500 & 76,580 & 1.00 \\
7.35 & 67,840 & 0.89 & 5.25 & 81,271 & 1.06 & 2.625 & 77,733 & 1.02 \\
7.70 & 60,163 & 0.79 & 5.50 & 86,237 & 1.13 & 2.750 & 78,909 & 1.03 \\
8.05 & 53,413 & 0.70 & 5.75 & 91,494 & 1.19 & 2.875 & 80,110 & 1.05 \\
8.40 & 47,470 & 0.62 & 6.00 & 97,058 & 1.27 & 3.000 & 81,336 & 1.06 \\
Average & 80,732 & 1.06 & & 77,451 & 1.01 & & 76,658 & 1.00 \\
Std. Dev. & 26,754 & 0.35 & & 12,587 & 0.16 & & 3,129 & 0.04 \\
\hline
\end{tabular}

\begin{tabular}{cccccc}
\hline & Mortality & \multicolumn{4}{c}{ Retirement Age } \\
Mortality & Liability (L) & Ratio (L/Base) & Retirement & Liability (L) & Ratio (L/Base) \\
\hline 75.600 & 38,993 & 0.51 & 52.00 & 114,282 & 1.49 \\
80.325 & 51,413 & 0.67 & 55.25 & 104,392 & 1.36 \\
85.050 & 61,551 & 0.80 & 58.50 & 94,839 & 1.24 \\
89.775 & 69,826 & 0.91 & 61.75 & 85,582 & 1.12 \\
94.500 & 76,580 & 1.00 & 65.00 & 76,580 & 1.00 \\
99.225 & 82,094 & 1.07 & 68.25 & 67,796 & 0.89 \\
103.950 & 86,594 & 1.13 & 71.50 & 59,189 & 0.77 \\
108.675 & 90,268 & 1.18 & 74.75 & 50,722 & 0.66 \\
113.400 & 93,267 & 1.22 & 78.00 & 42,355 & 0.55 \\
Average & 72,287 & 0.94 & & 77,304 & 1.01 \\
Std. Dev. & 18,535 & 0.24 & & 24,557 & 0.32 \\
\hline
\end{tabular}




\section{APPENDIX 6: MINIMUM FUNDING VALUATION}

This table displays the value of the pension fund liability calculated under minimum funding valuation assuming that each input ranges between plus and minus $20 \%$ of their base value, while all other inputs are held constant at their base values. The key inputs are discount rate, salary growth, pension increases, retirement age and mortality. Their base values are 7.75\% (and 4.50\%), 5.00\%, 2.50\%, 65 and 94.5 years of age, respectively. The average and standard deviation pension fund liability and the ratio of the pension fund liability to the base case (L/Base) are reported in the remaining rows.

\begin{tabular}{|c|c|c|c|c|c|c|c|c|c|}
\hline \multicolumn{3}{|c|}{ Discount Rate (DR) } & \multicolumn{4}{|c|}{ Salary Growth (SG) } & \multicolumn{3}{|c|}{ Pension Increase (PI) } \\
\hline$D R$ & \multicolumn{2}{|c|}{ Liability (L) Ratio (L/Base) } & SG & \multicolumn{3}{|c|}{ Liability (L) Ratio (L/Base) } & $P I$ & \multicolumn{2}{|c|}{ Liability (L) Ratio (L/Base) } \\
\hline $6.20 / 3.60$ & 81,986 & 1.62 & 4.00 & 50,490 & \multicolumn{2}{|c|}{1.00} & 2.000 & 47,222 & 0.94 \\
\hline $6.59 / 3.83$ & 72,456 & 1.44 & 4.25 & 50,490 & \multicolumn{2}{|c|}{1.00} & 2.125 & 48,012 & 0.95 \\
\hline $6.98 / 4.05$ & 64,170 & 1.27 & 4.50 & 50,490 & \multicolumn{2}{|c|}{1.00} & 2.250 & 48,820 & 0.97 \\
\hline $7.36 / 4.28$ & 56,928 & 1.13 & 4.75 & 50,490 & \multicolumn{2}{|c|}{1.00} & 2.375 & 49,646 & 0.98 \\
\hline $7.75 / 4.50$ & 50,490 & 1.00 & 5.00 & 50,490 & \multicolumn{2}{|c|}{1.00} & 2.500 & 50,490 & 1.00 \\
\hline $8.14 / 4.73$ & 44,753 & 0.89 & 5.25 & 50,490 & \multicolumn{2}{|c|}{1.00} & 2.625 & 51,352 & 1.02 \\
\hline $8.53 / 4.95$ & 39,748 & 0.79 & 5.50 & 50,490 & \multicolumn{2}{|c|}{1.00} & 2.750 & 52,234 & 1.03 \\
\hline $8.92 / 5.18$ & 35,282 & 0.70 & 5.75 & 50,490 & \multicolumn{2}{|c|}{1.00} & 2.875 & 53,136 & 1.05 \\
\hline $9.30 / 5.40$ & 31,452 & 0.62 & 6.00 & 50,490 & \multicolumn{2}{|c|}{1.00} & 3.000 & 54,057 & 1.07 \\
\hline Average & 53,029 & 1.05 & & 50,490 & \multicolumn{2}{|c|}{1.00} & & 50,552 & 1.00 \\
\hline \multirow[t]{14}{*}{ Std. Dev. } & 17,274 & 0.34 & & 0 & \multicolumn{2}{|c|}{0.00} & & 2,339 & 0.04 \\
\hline & \multicolumn{4}{|c|}{ Retirement Age } & \multicolumn{4}{|c|}{ Mortality } & \\
\hline & Retirement & Liability (L) & Ratio (L & (L/Base) & Mortality & Liabil & lity (L) & Ratio (L/Base) & \\
\hline & 52.00 & 121,796 & & .41 & 75.600 & 21 & 522 & 0.43 & \\
\hline & 55.25 & 98,835 & & .96 & 80.325 & 29 & 784 & 0.59 & \\
\hline & 58.50 & 79,678 & & .58 & 85.050 & 37 & 325 & 0.74 & \\
\hline & 61.75 & 63,731 & & .26 & 89.775 & 44 & 207 & 0.88 & \\
\hline & 65.00 & 50,490 & & .00 & 94.500 & 50 & 490 & 1.00 & \\
\hline & 68.25 & 39,527 & & .78 & 99.225 & 56 & 224 & I.II & \\
\hline & 71.50 & 30,480 & & .60 & 103.950 & 61, & 457 & 1.22 & \\
\hline & 74.75 & 23,042 & & .46 & 108.675 & 66 & 234 & 1.31 & \\
\hline & 78.00 & 16,953 & & .34 & I I 3.400 & 70 & 594 & 1.40 & \\
\hline & Average & 58,281 & & .15 & & 48 & 649 & 0.96 & \\
\hline & Std. Dev. & 35,884 & & .71 & & 16 & 790 & 0.33 & \\
\hline
\end{tabular}

\section{REFERENCES}

Attain Consulting (2009). Accounting for Pensions in Ireland - Part 2: Don't Discount the Discount Rate, available from: <www.attain.ie/what-we-think/reports/pensions/accounting-forpensions-in-ireland-part-2-december-2008/>, accessed 5 September 2013. 
Blake, D., Khorasanee, Z., Pickles, J. and Tyrrall, D. (2008). An Unreal Number: How Company Pension Accounting Fosters an Illusion of Certainty, London: Institute of Chartered Accountants in England and Wales.

Connell, P. (2007). Demographics: What Is Known and What Is Unknown? in G. Hughes and J. Stewart (eds.), Choosing Your Future -How to Reform Ireland's Pension System, Dublin: New Island.

Coughlan, G., Epstein, D., Ong, A., Sinha, A., Hevia-Portocarrero, J., Gingrich, E., KhalafAllah, M. and Joseph, P. (2007). LifeMetrics: A Toolkit for Measuring and Managing Longevity and Mortality Risks, technical document, 13 March, JP Morgan.

Delaney, H. (2007). Equity and the Law of Trusts in Ireland, Dublin: Round Hall Ltd.

Gohdes, A. and Baach, E. (2004). Rechnungszins und Inflationsrate für die Betriebliche Altersversorgung, Betreibs-Berater, Vol. 59, No. 47, pp. 2571-2573.

Goode, R. (1993). The Goode Report on UK Pensions Law, London: Her Majesty's Stationery Office.

International Accounting Standards Board (2008). IAS 19: Employee Benefits, available from: $<$ www.ifrs.org/Documents/IAS19.pdf>, accessed 20 August 2013.

Lane Clarke \& Peacock (2008). Accounting for Pensions 2008: UK and International, available from: <http://www.lcpnl.com/media/240643/afp_uk_and_international_survey_2008. pdf $>$, accessed 20 August 2013.

Lane Clarke \& Peacock Ireland (2009). Pension Accounting Briefing 2009: An Insight into Irish Defined Benefit Pension Plans, available from: <www.lcpireland.com/news-andpublications/publications-and-research/2009/pensions-accounting-briefing-2009/>, accessed 5 September 2013.

MacDonald, A.S. (1993). What Is the Value of a Valuation?, Proceedings of the Third Actuarial Approach to Financial Risks International Colloquia, Vol. 3, available from: <www.actuaries. org/AFIR/Colloquia/Rome/MacDonald.pdf>, accessed 20 August 2013.

May, G., Querner, I. and Schmitz, U. (2005). Entwicklung von Zinskurven für Zwecke der Bilanzierung nach IFRS/US-GAAP, Der Betreib, Vol. 58, No. 23, pp. 1229-1237.

O'Brien, C., Woods, M. and Billings, M. (2010). Pension Risk Disclosures by FTSE 100 Companies, Edinburgh: The Institute of Chartered Accountants of Scotland.

Pemberton, J. (1998). The Value of Actuarial Values, paper presented to the Staple Inn Actuarial Society, 17 February, available from: <www.sias.org.uk/view_paper?id= ValueActuarialValues $>$, accessed 20 August 2013.

Pensions Board (2009). Annual Report and Accounts 2008, Dublin: Pensions Board.

Society of Actuaries in Ireland (2008). Submission to the Department of Social and Family Affairs on the Green Paper on Pensions, available from: <https://web.actuaries.ie/sites/default/ files/story/2008/05/Submission_to_the_Department_of_Social_and_Family_Affairs_ on_the_Green_Paper_on_Pensions/080528\%20SAI\%20Reponse \% 20to\%20Green \% 20 Paper\%20on\%20Pensions.pdf>, accessed 20 August 2013.

Society of Actuaries in Ireland (2010). Actuarial Standard of Practice PEN 1 Funding Defined Benefits - Actuarial Reports, available from: <https://web.actuaries.ie/standards/asp/ asp-pen-1>, accessed 20 August 2013.

Society of Actuaries in Ireland (2012). Actuarial Standard of Practice PEN 2 Retirement Benefit Schemes - Transfer Values, available from: <https://web.actuaries.ie/standards/asp/asppen-2>, accessed 20 August 2013.

Society of Actuaries in Ireland (2013). Actuarial Standard of Practice PEN 3 Actuarial Funding Certificates and Actuarial Statements under the Pensions Act 1990, available from: <https:// web.actuaries.ie/standards/asp/asp-pen-3>, accessed 20 August 2013. 